\title{
Cross-Border Marriages between Residents of South Kosovo and Western Europe Discourses, Aspirations and Realities
}

DOI 10.17234/9789531756525.7

\author{
Carolin Leutloff-Grandits \\ Viadrina Center B/ORDERS IN MOTION, Europa-Universität Viadrina \\ Postgebäude, Logenstr. 9-10, 15230 Frankfurt (Oder), Germany \\ Leutloff@europa-uni.de
}

For the inhabitants of Kosovo, marriage migration is one of the few legal forms to enter the EU with a long-term perspective. Still, based on the perception that it fosters the immigration of cultural "Others", and that especially women may be victims of such marriages, various EU member states also restrict the immigration of family members. This study wants to shed light on the emic view of spouses upon such marriages. Relying on fieldwork in rural Kosovo as well as among migrants from Kosovo in Austria and Germany, the author takes notice of a locational and gendered perspective on imaginations as well as the realities of cross-border marriages within the family and household arrangements.

Keywords: cross-border marriages, marriage-migrants, Kosovo, Southeastern Europe, Western Europe

\section{Introduction}

$\mathrm{W}$ That has been striking to me during my fieldwork in the south of Kosovo, ${ }^{1}$ in the region of Opoja, was the finding that nearly half of all marriages that were registered in this municipality involved a spouse who lived abroad, and entailed the prospect of outmigration of the marriage partner living in south Kosovo. Such cross-border marriages established an important means of migration into Western (European, but also Overseas) countries, not at least because other migration options were meagre. In fact, in the region of Opoja,

\footnotetext{
This article goes back to a long term social anthropological research which I started in 2011 in Kosovo on transnational family solidarity between people from the rural region in south Kosovo, called Opoja, and migrants from this region living abroad, and here especially in Germany and Austria, and which was financed by a research grant of the Austrian Science Foundation (Project No D 22659-G18). My special thanks go to Karl Kaser, Blerina Leka, Tahir Latifi and Eli Krasniqi, who collaborated with me in the project. Parts of this text are based on the article LeutloffGrandits 2015.
} 
international labour migration to Western Europe had become an important means of livelihood already from the 1960s on. Up to the late 1980s, mainly men went abroad and left their wife and children within the paternal household in the village. When, in early 1990s, the EU states began to limit migration possibilities, while at the same time ethnic conflict escalated in Kosovo when Serbia annulled the autonomous state of Kosovo and excluded Albanians from public services, many Albanian inhabitants of Kosovo crossed EU borders as refugees and asylum seekers, among them also women and children, and sometimes they entered via family reunion programs. In 1998, this conflict developed into a full-fledged war. After the end of war in summer 1999, the situation in Kosovo did not improve as hoped for and, at the same time, the general outlook for emigration had further deteriorated (Hockenoes 2006) and was reduced to family unification. ${ }^{2}$ In this situation, marriage migration, in which a migrant married a spouse of his or her home region - became the main means of moving abroad. In fact, many young people in Opoja, men as well as women, aspired to marry a migrant from this region living in a Western European country in order to start a life abroad.

In this article, I want to look at the different views on such cross-border marriages. For that, I rely on a sequence of six several-week-long social-anthropological fieldwork units in the region of Opoja in Kosovo from 2011 to 2013, where I did participant observation of the village life and interviewed numerous villagers as well as visiting migrants - among them young people as well as their parents - about their family life and future prospects. At the time of my fieldwork, many of them either wanted (their children) to marry abroad, were engaged with a migrant from abroad, or had already married a migrant and were waiting to move abroad, or even had already moved abroad. Due to the longer period of the research from 2011 to 2013, I could observe the coming to be of such cross-border marriages and also follow the developments within the families and the marriages of young people, not at least through multiple visits and interviews, and also by visiting migrants in Austria and Germany. With this, I could achieve a nuanced understanding of such cross-border marriages. ${ }^{3}$

Based on this fieldwork material, the question I wish to pose is what kind of gender roles are transported within such imaginaries, and to ask in which way gender roles are re-produced and transformed in a transnational space. In reference to

2 In fact, although educational mobility is a way to go abroad and bears a lot of hopes for young people in Opoja, who want to use it as a means to upgrade their situation at home and to have new, cosmopolitan experiences, it is very difficult to achieve these goals due to the economic pressures under which students find themselves abroad.

3 The fact that the inhabitants of the region of Opoja are of Muslim faith is - in my view - not an explanatory reason for cross-border marriages, which are also practiced among catholic Albanians from Kosovo. 
Appadurai (2005: 33), ${ }^{4}$ such cross-border marriages create cross-border "marriagescapes", which are formed through social, economic and political relations across state borders, as other transnational "scapes" do (see also Lauser 2005). Based on different viewpoints and perspectives, such scapes appear to differ from each other according to gender and generation, as they are formed in everyday life through context, experience and imaginations (Constable 2005: 4). In relation to Doreen Massey's definition of "power geometry" (1994: 149), it makes sense to observe the divergent positions of people in relation to their access to power and participation in political and societal realms (Constable 2005: 14). ${ }^{5}$

In the following, I start with the discourses as well as legal measures on crossborder marriages within the receiving society, as they frame marriage migration. I then move to the emic perspective of young people from Opoja, in the south of Kosovo, who want to marry a spouse living in Western Europe, and describe the forms and meanings of spousal choice in the Opoja region today. In order to do so, I assume a gender sensitive and locational perspective. In a further section, I will concentrate on the coming about of cross-border marriages. Here I wish to discuss in which way their imaginations of cross-border marriages could be fulfilled and what kind of opportunities, but also challenges this entailed. This includes family and household arrangements, in which the newly married couples live, because possibilities and conflicts often manifest themselves within these domains.

\section{Discourses of and legal measures against marriage migration within Germany and Austria}

Within the receiving society, marriage migration is often regarded as an intraethnic phenomenon, one that the migrants who marry a spouse from their home region are pushing forward (Beck-Gernsheim 2007; Timmerman 2006; Schröttle 2007; Gutekunst 2016). This view of cross-border marriages as an intraethnic phenomenon is dominant disregarding the fact that such marriages are increasingly common between men from Western countries and women from non-Western countries (and here Russia and Asian countries are at the top of the list) (Constable 2005; Ruenkaew 2003). Moreover, cross-border marriages between migrants ${ }^{6}$ and

4 Appadurai (2005: 33) calls this "ethnoscapes, mediascapes, technoscapes, financescapes and ideoscapes".

5 In the US an over-proportional number of migrants are female, which holds especially true for marriage migrants. Furthermore, the number of marriage migrants has been tripled between 1960 and 1997 and raised from 9 to 25 percent of all migrants (Constable 2005: 4).

6 Regardless of whether they belong to the so-called first generation (meaning that they arrived abroad at school age or later) or to the second generation (meaning that they arrived at pre-school age or were born abroad). 
partners from their home regions, as is the case in Opoja, are often culturalized and problematized in mainstream Western discourses (Strasser and Tosic 2014; Pellander 2015; Bonjour and Block 2016).

Based on the literature which analyses the public notions of cross-border marriages in EU states, it is widely assumed that cross-border marriages in which immigrants marry a partner from within their own ethnic group, and "even" from their so-perceived country of origin, postpones or even blocks integration of migrants into the receiving society, as the partnership with a newly-arriving migrant - based on so-perceived different cultural values - postpones the process of integration. The choice to marry someone from the home context is seen as a sign that migrants want to remain among themselves, and that they do not want to integrate into the receiving society (Beck-Gernsheim 2006; Strasser and Tosic 2014). ${ }^{7}$ Following this logic, it is anticipated that with marriage migration, migrant communities may "rejuvenate" themselves. In Austria in the 1990s, this notion found expression in the slogan "Integration statt Neuzuzug" (integration instead of new arrivals) - assuming that marriage migration and family reunion would hinder integration (instead of fostering it) (Strasser and Tosic 2014: 131).

Another perspective on marriage migration as a cultural practice is even more problem-centred, as it anticipates that such marriages, and especially among certain migrant groups (e.g. Albanian, Turkish, Pakistani or Tamil) would follow patriarchal family arrangements, being backward and non-modern. This view is often contrasted to "Western" marriages, which are seen as based on love and as emancipated. It is furthermore anticipated that such marriages are fertile ground for "forced marriages" as well as violence within such marriages (Bonjour and Block 2016; Razack 2004). Women are, in particular, seen as pressured or even forced into, as well as exploited within such cross-border marriages, no matter if the woman is the one migrating for marriage or if she is the one who enables someone to migrate for marriage (Kelek 2006; compare also Beck-Gernsheim 2007; Schmidt 2011: 56; Timmerman 2006: 125-126; Straßburger 2001; Neubauer and Dahinden 2012; Charsley 2005). ${ }^{8}$

This may include that migrants abuse the institution of marriage for other purposes, e.g. to use cross-border marriages as "entry tickets" into Western European countries (see notions of "Scheinehe" - sham marriage or "Zweckehe" - marriage of convenience). A marriage between a migrant and someone from the receiving society is on the other hand seen as a sign of a successful integration (Charsley and Wray 2015; Charsley and Liverage 2015; Block 2014; Straßburger and Aybeck 2015; Beck-Gernsheim 2006: 112).

8 It is furthermore not asked if the differentiation between migrants and members of the majority population makes sense in this regard, as also non-migrants can experience force in marriages (Riaño and Dahinden 2010: 23). This again leads to research designs in which the situation of migrant women as victims is explored, e.g. by taking organizations that deal with such victims of "forced marriages" as a starting point for research, thus blending out non-violent forms of marriages, and often also the perspective of men (an exception is Toprak 2007). The insights of these studies are then generalized and taken as absolute manifestations of such marriages. 
With these notions, it is thus no wonder that legal measures are set against such marriages, making it generally more difficult to allow migration of a partner with non-EU citizenship on the basis of marriage. In various EU countries, the introduction of an age requirement for marriage migrants ${ }^{9}$ was one important measure against so-perceived "forced marriages", anticipating that an older age would leave potential marriage partners more space for own decisions (Block and Bonjour 2013; Bonjour and Block 2016). This led to a drop in the number of marriage migrants.

Another measure demands of those migrants who want to join their partners or families in Germany and Austria (in Austria, this law is valid since 2011) to provide proof of some basic knowledge of German language before migration - thus shifting the "plea of integration" already before arrival in the immigration country and even beyond the borders of the state (at least as soon as they do not belong to a certain stratum of economically preferred migrants). ${ }^{10}$ This measure followed the demand for integration from the side of migrants, which was articulated by the Austrian conservative government in the 1990s. In Austria, for example, migrants have been obliged to successfully complete language and integration courses in order to qualify for residency rights and, later, for citizenship rights since 1998.

Although "love" is valued as the supreme reason for marriage in Western European states, this also means that immigration states do not accept "love" as sufficient for a cross-border marriage, but force migrants who want to bring their marriage partner over or those who want to move abroad on the basis of marriage to consider the legal frames and technical matters, while at the same time suspecting cross-border marriages to be based on instrumental reasons. Such restrictions thus clearly intervene in the realm of intimacy, partnership and family planning.

These measures against anticipated "forced marriages" concentrate on the phase before the actual migration takes place, while not regarding that the perception of force does not have to necessarily occur only within the process of entering a marriage, but also may come up and change within different stages of the marriage, and that power relations and imaginations can change during such marriages. In fact, as Riaño and Dahinden (2010) have shown, it is more frequent that marriage

9 In Germany, the minimum age of marriage across state borders was raised to eighteen in 2007 (whereas the marriageable age in Germany is sixteen), and to twenty-one in Austria (Strasser and Tosic 2014: 143) and the Netherlands (introduced in 2004) (Bonjour and Block 2016: 790).

10 This also entailed measures for the easier arrival of higher qualified migrants and workers in certain professions in demand, which also included an easier approach for family reunion - including the omission of proof of language proficiency. This means that integration was increasingly measured on capacity for and performance within the labour market (cf. Strasser and Tosic 2014: 131-133). With the so-called "Rot-Weiss-Rot-Karte", wanted mobility is supported, while unwanted mobility is hindered. 
partners experience force after they get married (compared to the experience of force or pressure to marry a certain partner against their will). Legal frames are however not necessarily supportive as soon as marriage migrants try to dissolve such a marriage as, within the first three years of marriage, residency rights are bound to the marriage partner.

\section{Partner selection in Opoja: past and present}

The notions of culturally different forms of marriage that can be found in public discourses and legal measures in Germany and Austria do not come out of the blue. In fact, also in social sciences, marriage forms have been regularly linked to different types of society within theories of modernization, thus creating a hegemonic classification of marriages. Giddens (1992: 2-3, 38-41) linked "arranged marriages" to pre-modern, kin-centred societal arrangements based on economic necessity and male privilege, and "love marriages" as well as intimate relations between spouses to highly individualized and modernized societies, which according to this logic also leads to more equality between sexes. According to Kohli and Heady (2010), such marriage models also historically find a geographical expression: while the first model is typical for northern and western Europe, the second model has been typical for southern and eastern Europe. In fact, these notions also go back to historical family studies (e.g. Hajnal 1965; Kaser 1995).

Turning now to Opoja, I found it striking that almost all middle-aged and elderly people I talked to in Opoja, but also many young people, explained to me that the forms of spousal choice changed rapidly after the end of war in 1999, and that they evaluated this with the parameters of modernity and backwardness. While in the 1990s and previously, parents had predominately selected the spouses for their children, partly even without the consultation of the young people (see also Reineck 1991), at the time of my fieldwork from 2011 to 2013, many people regarded such arranged marriages as out-dated and pre-modern. My interlocutors stressed that they were the absolute minority now, as the vast majority of young people chose their own partners, and that pre-marital romantic relations had become more common in Opoja since the end of the war, thus emphasizing individual choice, affection and partnership within a marriage.

According to my observations, the reality of spousal choice, however, included both aspects - arrangement and romances - in a "hybridized" way. ${ }^{11}$ While in all cases I followed, the young people had the last say in the decision about their partner, family members were in different forms involved in the engagement pro-

11 This is also the case in contemporary Turkey (see Hart 2007) as well as among migrants from Lebanon in Australia (see Hyndman-Rizk 2016). 
cess. ${ }^{12}$ What differed was how the young people got to know their partner. In "love marriages", young people had got to know each other outside the family context, e.g. in school, and had fallen in love with each other, but many young women were pressured to marry soon after their parents got to know that she was dating a young man. Based on local traditions and high unemployment, these young women then often became mothers and housewives, and the large majority of women in the villages did not take up wage work after marriage. In "arranged marriages", on the other hand, young people found their partner through proposals by relatives, but the very procedure of arranged marriages had changed, and individual opinions, desires, and the prospects of the young people were put more into the centre. A girl might choose from multiple offers according to criteria like the character and education of the person, the family background and household structure, the income of the household and the status of the family - and then testing during their mutual meeting whether the two like each other. The phase between engagement and marriage is used to build up a romantic relationship, in which spouses contacted each other on social media and regularly went out together.

Due to the different prospects and considerations concerning "arranged" and "love" marriages, the method of partner selection partly differs not only from family to family, but also within families and among siblings. The manner of choosing a spouse is often tied to the character and preferences of the young people themselves, who may be too shy and obedient for developing a romantic relationship on their own, or who are too self-conscious and flirtatious not to fall in love with a colleague at school. Maybe even more importantly, some young people opted for family counselling because they wanted to go abroad rather than stay in their home region, and thus were hoping to get to know a potential marriage candidate via family proposals. An "arranged marriage" was thus a self-conscious decision in order to achieve a better future, which was contrasted to a prospective life in their home region in Kosovo's rural south. These young people experienced the village as a realm of limited possibilities, while migration seemed to create new, better possibilities, and seemed to strengthen their own role as an actor, while at the same time also strengthening the role of the family. Such visions were however also gendered.

\section{Women aspiring to marry abroad}

Young women who wanted to marry abroad often linked this to their wish to escape poverty and their longing for material prosperity, comfort and a better future

12 In fact, the influence of the family on partner selection is likely wider than in "average" Western European marriages, but we must not forget that this influence is there, too - as most individuals marry within their (social and cultural) group. Such choices are based on internalised social norms gained through socialisation within the family and society, but such norms get little attention. 
for their own children. ${ }^{13}$ They partly also hoped to achieve more individual freedom as well as a partner-like relationship with their prospective spouse, contrasting their hopes of a marriage abroad with their restricted economic possibilities and the patriarchal gender relations in the villages in Opoja despite the major changes that occurred after the war. Based on the consumption of daily media, social networks as well as on the visits of migrants, young people in Opoja knew that women can take over other identities outside the region, leaving traditional roles behind and enjoying more freedom. ${ }^{14}$ They hoped to be able to take up wage work and thus to contribute to the household income, or even to continue with their education and take up a high(er) qualified job abroad.

Flora is an 18-year-old young woman from Opoja who had recently finished gymnasium. As her parents could not afford to pay university education for her and did not want her to work outside the household, she remained at home from that day on. Although she considered herself to be too young for a marriage, she said that she wanted to marry abroad, as she experienced the village like a prison that she could not leave. She thus also did not want to marry one of the young men from the neighbouring villages (and she told me that she would have had the opportunity for that if she had wanted), but instead directed her hopes at a (still anonymous) migrant.

Young women like Flora also had various concerns about cross-border marriages, which stemmed from negative experiences of others that they had learnt about. In fact, they were aware that the position of brides abroad was often difficult, and that young women from Opoja enjoyed a certain reputation of being obedient and submissive among migrants abroad - a reputation which they do not necessarily see as good. The 20-year-old Spresa, who is engaged with a man living in Opoja, said for example critically: "They take a bride because they think that she is stupid..."

Young women thus carefully looked out for a "good" young man and also checked his family background, and thus also welcomed the advice of family members who had certain information about the respective marriage candidates and their families. Flora, for example, hoped to receive a proposal with the help of a relative from abroad, as this seemed to be a more serious option for her. Only after initial contact was established, she could imagine chatting with the prospective marriage candidate via Internet in order to establish a romantic relationship and later make her decision about a possible future marriage.

13 That this is nothing specific for women from Opoja, but a motif found more or less universally, has been described by Appadurai (2004, 2005) and Beck-Gernsheim (2011: 62).

14 Again this is not exclusive for women from Opoja in Kosovo. Bhalla (2014) describes that also Indian women who marry into the USA hope to leave traditional structure behind and be able to create prosperity and a better future. 
When I met Dafina, who was about 30 years old, she had recently gotten engaged with a migrant who lived in Germany and who was proposed to her by a relative. She was already relatively old for getting married compared to other women in the region, and as she had only an eight-year school education, she had been at home for about 15 years already. When I asked her what she had done the years after school, she explained she had always wanted to marry a migrant in order to offer her prospective children a better future and possibilities that she had not had herself, like a better school education and the possibility to take up a profession. She wanted to learn German abroad in order to take up wage work and to contribute to the household income. She was, however, also concerned about falling prey to the wrong one, and she wanted to find a man who was family-oriented and not a dodger.

After various proposals, which her parents received and in which relatives had brokered, there was finally a proposal that met her expectations: he was a migrant from the region who was in his late 30s and who owned his own firm and had a good income. She added that he also did not have an earring or a beard, explaining to me that these were suspicious signs of a too strong individualization and westernization, or also of religious "fanaticism", as villagers often referred to their negative image of fundamentalist Islam. She also evaluated it as positive that he lived in a nuclear household as he had no relatives abroad, as she then did not have to live with his parents and had less to fear regarding their influence.

Like Dafina, young women thus rely consciously on family counselling in order to pick the right one. However, the legal measures of the German and Austrian state to prevent "forced marriages" sometimes affected them rather negatively. In Opoja, I encountered for example various young women who had to wait for the papers to join their husbands in Austria, some of them for even more than one year or several years, because they either got engaged before the age of 21 (as many had finished school at 16) or because other legal requirements had not been met. Some confessed that the situation created insecurities and burdens, as it questioned the stability of the relationship already before marriage, and because the young people in Opoja had only very limited power to influence it. Young women, who had looked to life abroad with excitement and happiness, suddenly found themselves in doubts and worries.

When the German and Austrian state introduced an obligatory proof of beginners' knowledge in German for migrating family members in 2007 and 2011 respectively (Block and Bonjour 2013: 207; Gutekunst 2016), various marriage migrants then also started attending German language courses offered by a language teachers in the region in order to pass the official German language examination held by (a partner of) the German Goethe-Institute in Prishtina. ${ }^{15}$ While this helped them to develop basic German skills - an ability much needed abroad - and made them

15 See www.goethe.de/lrn/prj/egn/deindex/htm (last access 27 November 2017). 
proud as soon as they managed to learn and pass the test, it also put many of them under considerable pressure as they were not used to learning a foreign language, and they also experienced difficulties related to organising their participation in the course and paying for it. ${ }^{16}$ In many cases, the language test became thus another barrier to pass for being able to marry abroad.

Thirty-year-old Dafina, for example, started to attend a private German language course in a neighbouring village after engagement. During my conversation with her, Dafina confessed that she felt under considerable pressure to pass the course, not at least because she believed that her husband and his family abroad saw her passing as a kind of precondition for marrying her. In fact, during the course, Dafina got nervous and partly also desperate about it, as she had left school more than ten years ago and learning and even reading was difficult for her. While she was learning, her eyes and head started hurting a lot, and she even developed severe tooth pain. As I had heard of such symptoms and pressures also from others, it is thus questionable whether it is helpful to start with the plea for integration already in the sending countries - as this shifts the border and puts the pressure one-sidedly on the prospective marriage migrants. Within their limited frame, however, women were not only victims, but also actors: Desa for example, who agreed to an engagement with a migrant after family counselling, dissolved the engagement after half a year when she realized that her prospective spouse was not supportive enough of her. This negatively affected her social status as well as that of her family, but it brought her also respect.

\section{Men aspiring to marry abroad}

Many young men from Opoja also wanted to marry a migrant from the region in order to migrate themselves. The reasons are first of all economic. Because of the high regional unemployment rate of $27.6 \%$ and even $52.4 \%$ among the age group of 15-24 in Kosovo in 2016, and even higher numbers in Opoja, ${ }^{17}$ and the low earning potential in private employments, many see very little perspective for themselves in Kosovo, let alone in the region of Opoja. This applies especially to young men without any higher education, either because they were not good pupils or because

16 As such a course is only offered in one village within Opoja that is not accessible by public transport from various other villages, most participants have difficulties to commute to the course. Furthermore, the costs for the language course need to be covered privately (and is often covered by the (family of the) prospective husband), which puts additional pressure in these marriages.

17 See Kosovo Agency for Statistics, Results of the Labour Force Survey in Kosovo (LFS), 2016. Furthermore, inactive work force is quite high $(61.3 \%)$, with an emphasis on females at $81.4 \%$ compared to males $(41.7 \%)$, and only $29.5 \%$ of employed persons have permanent contracts in their main job, while $70.5 \%$ have a temporary contract. See for a good analysis of the labour market also Latifi 2016. 
their parents did not have enough money to support their further education. They hoped to receive a well-paid job abroad and tended to ignore the negative aspects, often against better knowledge. ${ }^{18}$ However, young men who studied also wanted to marry abroad, as they experienced that in Kosovo their job chances were restricted also in the higher professional sectors. While some were willing to take "any kind of job", others hoped to be able to continue their studies abroad, after marriage.

This was the case of the 28-year-old Agim, who came from a well-educated and ambitious, but not very prosperous family with six siblings. Agim completed his BA in Prishtina with best marks, but he said that the distribution of the few jobs that existed in Kosovo was based on clientelism and corruption, and he thus wanted to continue his education abroad in order to take up a well-paid job there. When he got to know a young woman who lived abroad through the counselling of relatives, both started a romance and agreed to the marriage soon. She then enabled him to go abroad and realize his dream of studying abroad.

Many young men, however, did not have only themselves and the fulfilment of their individual prospects in mind when aiming at a cross-border marriage, but regarded it as a family matter. They were willing to financially support their parents and siblings with their migration, as it is above all a social norm in Kosovo that sons care for their elderly parents (and siblings), while state social security is rudimentary. One young man who had married abroad the year before told me for example that he had never aspired to live abroad, but when his parents came up with the opportunity of a cross-border marriage, he agreed to it in order to secure his own future and the future of his family at home.

But other family as well as individual considerations were also of deciding importance. Young men were aware of the fact that they would be able to found a nuclear household with their wife in migration, often even with the financial support of the bride's parents, as it is against the Kosovo-Albanian tradition to move into the household of the bride's parents. At home, however, many of those young men had to share a household with their parents and partly also with their siblings in the rural context in Kosovo - until the family had managed to save enough money to build a new house (or several of them). This implies that they have to adhere to the authority of their father. As the life worlds of the young people and their parents have diverged, especially owing to the use of electronic media, some young men wanted to migrate in order to escape the father's authority in order to avoid potential conflicts.

To succinctly describe the perspective of migrants abroad who are willing to marry someone from Opoja - and of course not all marry a migrant from the

18 Timmerman has also observed this "blending out" of negative factors for young men from Emirdag in Turkey who wanted to migrate to Flanders (2008: 590). 
home region in Kosovo, many also want to marry another migrant - it can be said that those who do are conscious about the essentializing discourses about marriage migration prevailing in the majority society. Thus, they also position themselves according to these discourses. They, for example, say that they want to marry a partner from Opoja because of "cultural" reasons, and because they expect that their partners will be family-oriented. Furthermore, they often enjoy a special position in the home region in Kosovo, and have positive images about it based on the time they spent there during summer vacations.

\section{Realities of cross-border marriage life}

After migration, migrating spouses were in the beginning often highly dependent on their spouse - in legal terms, as their residency rights were bound with the marriage, and in economic terms because it took time to take up wage work, and not at least also in emotional terms, because they had to cope with a new environment and were socially rather isolated. I thus imagined that many difficulties and barriers existed within these marriages, which could reproduce but also redefine gender and partnership relations - dependent on the positioning and sex of the partners.

In fact, migrating men did not meet the same conditions as migrating women, not at least because the expectations about their economic productivity and their position within the partnership were quite different. When I asked various interlocutors if men who wanted to follow their brides abroad would fear losing power and becoming dependent on their wives, men as well as women frequently answered that I did not know men from Opoja, as they would never feel inferior to their wives and were very self-confident. Considering these answers, I realized that migrating men had little social space to define personal problems or express feelings of fear or despair, although it was unquestionable that they faced difficulties abroad.

Next to establishing a life-long partnership as a basis for a family, men were expected and expected of themselves to take up a job and earn a living for their families. After migration, these expectations were however not easy to fulfil, as many men had difficulties establishing themselves in the majority society and becoming the main breadwinners - although women often supported them in achieving this. In fact, most women who married a groom from Opoja had taken up wage work before marriage. They continued to work also after marriage, while their husbands who arrived from Opoja had to find work first, and they then often had to take a job that was paid less than the one their wife had. But women also took care to balance power relations as best as possible. Fatmire for example enabled her husband to access her bank account when he did not have his own salary. The joint account was then kept until today and both can take money from the account. This makes it less obvious that she earns more money. 
Still, Fatmire has silently taken over the management and administration of the household - a practice that she did not deliberately take up, but which just developed. Due to the lack of language proficiency and orientational knowledge of her husband, Fatmire told me that she supported him in different administrative tasks, like the application for residency and for social transfer payments. Fatmire took over the official correspondence as well as banking transactions for her husband. This somehow became a rule and they kept to it even years after her husband had joined her. This however also impacted on their relationship as well as the individual selfesteem and gender roles. In fact, she complained to me that she always has to commit herself to everything, while he had adopted a passive attitude. As Fatmire earns more than her husband, they face the situation that Fatmire needs to work full time in order to finance the family, while her husband is more involved in the care for the children. When she has to run some errands she sometimes does not even ask him to take over caring duties anymore, but just leaves the children at home with him. The role in which her husband found himself may be experienced as troublesome in various aspects as it does not comply with the gendered role expectations, which are widely shared within the local community in Opoja, and partly also among migrants from Opoja and other regions in Kosovo who live abroad. Fatmire's husband does not problematize his role, but rather withdraws to the private realm and rarely goes out with his fellows from Kosovo. This however contributes to his difficult standing also within the migrant community, in which other men consider him (and others like him) as a henpecked husband, who is "ruled" by his wife who might even prohibit him from going out.

In other cases, especially when women married a migrant with higher education, the subordinate position of the husband may be more temporary, and may lead to fewer conflicts and is easier to accept. This is the case of Endrit, who married abroad not at least because he wanted to continue his studies there. His wife Shega, who came to Austria at the age of twelve and worked as a pharmaceutical assistant after finishing a professional training in a pharmacy, was happy to marry a partner with a university education and with the prospect of receiving a good job. ${ }^{19}$ When he joined her abroad, she helped him to organize and finance his studies by working full time. After Endrit successfully finished his studies and managed to find a well-paid job, their partnership relations shifted again. He became the main breadwinner of the family and they also decided to have their first child, for which Shega remained at home for three years. However, she still helps him to fill out forms and looks over them again, as she has much more experience, not at least because she became the logistical leader of her natal family long before she met Endrit, when she had to translate for her parents and was involved in all decisions and administrative tasks. She also supported her younger sister, who recently started to study psychology.

19 In fact, achieving this was not easy at all, as Shega had to overcome various legal and social barriers. 
The position of marriage migrants and gender roles within the family also depend on family members who live close by and with whom they have regular contact. While male marriage migrants often establish a nuclear household with their wife abroad, most of the households of such cross-border marriage couples are located in close distance to the household of the bride's parents as well as those of siblings and/or other relatives of the bride. The geographical proximity of these households enables a close cooperation between them. In various cases, this is practiced daily or at least several times in a week. This means that with migration, men enter into the network of his wife's relatives, and they often also receive support from these networks, e.g. in terms of job search, finding and furnishing a flat, as well as regular hands-on support, which is rather unusual in the Opoja region.

The family network of the bride can however also be of special use for the bride herself. If she wants to take up wage work again after giving birth to children, and thus take over a breadwinner position (again), she can often count on her mother or sister to care for her child(ren) during her absence from home. Her own family networks can thus empower female spouses within their partnership, or create a space for emotional and practical support network independent from the partner (and his family), which may at times even exclude the partner. Fatmire for example lives close to her sister and the two see each other nearly daily and cooperate closely. Fatmire and her sister also take turns with childcare when the other has an important obligation for which the children are bothersome. This kind of cooperation among sisters, which has become even stronger after marriage, is unusual or even impossible in Opoja due to the geographical distance between villages, and also because of the patrilocal marriage pattern and family structures. Instead, they rather rely on their sister-in-law or their parents-in-law.

Women who migrated in order to join their spouse often wanted to enter employment and many took up wage work to a later point of time, too. But they were still far from being expected to do so by others, as they were expected to mainly care of the household and the children. This again reflects the widespread and traditional gender role model prevalent in many rural parts of Kosovo, which partially stretches to migration contexts owing to translocal or transnational family networks. However, those couples who had founded their own household particularly stressed in joint conversations with me that they had a partnership-based relationship with their spouses. Many male migrants, who had come to Germany or Austria as teens and who later married a woman from their home region, who came abroad via marriage, told me in individual conversations that they depended on their wife, who was more competent in childcare and household matters and who had the decision-making power in these realms. They also said that they discussed family matters jointly and, for example, did the weekly shopping of groceries together and visited relatives and friends jointly. 
In many cases, men were even very much interested in their wife taking up wage work. With this, they underlined their "modern" approach to partnership relations, while also stressing this was a very welcome contribution to the household. In order to finance the family abroad and to fulfil the financial expectations of relatives at home, most migrant households needed two breadwinners, especially when the salaries they earned were relatively low. Thus, many women who migrated abroad in order to follow their husbands soon started to take up wage work in order to contribute to the family income, e.g. by doing cleaning jobs or working in a factory. This also led to an empowerment of women, especially as soon as they could administer their salary. This is again nothing special for marriage migrants from Opoja, or Kosovo in general, but posed a normality also for many labour migrants who fetched their spouses from the 1970s on, or who migrated together. ${ }^{20}$

Some young women who went abroad via marriage do not live in a nuclear household with their husband, but share a household with their husband and his parents, and partly also with unmarried sisters and brothers or even with a married brother or sister in law and possibly also their children. In such household constellations it is clear that the relationship between the bride and the mother-in-law (and partly also to other female members) has a certain importance, as the women spend a lot of time together at home and often also divide the housework between each other. However, the relations between female marriage migrants and their in-laws are of different quality.

Like men who migrated on the basis of marriage, some in-marrying women who migrated abroad receive a lot of support from their mother-in-law and other female relatives of their husband in order to get acquainted to the new life circumstances. ${ }^{21}$ Members of her husband's family may also support the young bride in attending a language school and pursuing further education or wage work, e.g. by driving her, taking care of her children, or financing the courses.

However, the joint household situation in which the bride is living with the family of her husband can also create various burdens for the female marriage migrant. In fact, some in-marrying brides from Opoja, who lived abroad in larger family settings, told me that they faced a lot of family obligations in the household, which did not leave them much space for other things, and partly also restricted their movements and their possibilities to take up wage work and learn German. In fact, such a role model was partly supported by and expected from her motherin-law, who had often been integrated in the household of her own parents-in-law

20 See Morokvasic 1987 for migrants from former Yugoslavia; Schiffauer 1991 for migrants from Turkey.

21 Similar observations are made by Straßburger (2001: 12) for female marriage migrants from Turkey in Germany. 
in Opoja after marriage, where she took over a serving role for the household members, often in absence of her husband who worked abroad, while she moved abroad in order to join her husband only years later. Meeting such circumstances, such realities of cross-border marriages were in contrast to the imaginations young brides from Opoja had about their life abroad, and could become a heavy burden and a predicament.

This is the case of Blerina, who had been an excellent pupil at home in Opoja. She had married abroad in order to study medicine, but she was not allowed to attend university, or even German classes, and suffered a lot from the restrictions her mother-in-law imposed on her. After her arrival, she had to take care of the children of her sisters-in-law, who went to work regularly, and had to do the housework for the many household members as, along with her husband and parents-in-law, her brother-in-law and his family shared the same household. Being depressed, she thought about leaving the family and returning home. However, she then gave birth to a son in the meantime and leaving was no option any more, as she feared having to leave her son behind, and did not see an alternative future for herself. Being isolated and without hope, she was also not willing to involve outsiders into the conflict and possibly escalate it, but rather endured her situation. More generally, divorce meant the threat of being sent home again, as residence right was bound to the husband, and returning home meant losing honour and social status and facing the only option of marrying a widower sooner or later.

\section{Conclusions}

Different from widespread popular, but also scientific notions according to which "arranged" and "love" marriages are positioned at different poles, especially in terms of individualization, self-realization and freedom of choice, I have argued that in Opoja, these differences are blurred. In fact, today's "arranged marriages" in the Opoja region are increasingly based on the choices of the partners involved and also include a romantic phase, while "love marriages" are at the same time also family framed and the self-realization within such marriages may be limited. In cross-border marriages, the arrangement takes an even more important part in order to realize individual imaginations and future aspirations. An "arranged marriage" is thus not necessarily something that is "left over" from former times, but rather has experienced a revival in insecure economic times and of a neo-liberal, consumer oriented culture, and especially in relation to restricted migration regimes which leave nearly no other options for immigration.

However, while cross-border marriages are seen as the starting point for a better life, which is aspired by young women and men from Opoja alike, the realization of such imaginations is another side of the coin. As has been shown, gender positions 
and family relations matter considerably when imagining and evaluating such marriages. As marriage migration transcends large geographical distances and country borders, it can entail new forms of empowerment or disempowerment for women as well as men that are not unambiguous.

Generally, marriages in which women migrate from Opoja abroad entail very ambivalent possibilities for the women. On the one hand, such marriages might bring material benefits, and in some cases husbands might also push their wives to learn the language, enter wage work, and pursue further education - not only because this sooner or later contributes to the shared household, but also because they want to have an "emancipated partnership". In other cases, however, the imaginations women had when moving abroad may fail to materialize and women may instead be exposed to coercions and conflicts.

Such coercion within cross-border marriages is however not prevented by the legal measures mentioned in the beginning. For migrating women, divorce is often not seen as a solution, as they fear of losing their children, their rights to stay abroad, or their honour when returning, while facing only the option of re-marriage after some time. In fact, problems related to social isolation, the lack of (access to) state support and tenuous residency rights will not be solved through the criminalization of cross-border marriages. Instead, the latter only supports inner-familiar violence (see also Strasser and Tosic 2014: 144; Neubauer and Dahinden 2012).

In the case of marriages in which male partners migrated from Opoja in order to move to their wife abroad, the relations also differed between themselves. Based on the prevailing gender stereotypes according to which migrating men were expected to take up wage work and lead the household, men had difficulties in fulfilling the role model, especially in the beginning, and became to a certain degree dependent on their wife as well as her family, while the wife gained power within partnership relations. This was one of the reasons that led to partnership conflicts and individual crises, as men felt marginalized and downgraded. This may however also open up more partnership-based relations.

More generally, such marriage mobilities across state borders can lead to the crossing of gender boundaries and the questioning and new definition of "traditional" gender roles. 


\section{REFERENCES}

Appadurai, Arjun. 2004. "The Capacity to Aspire. Culture and the Terms of Recognition". In Culture and Public Action. A Cross Disciplinary Dialog in Development Policy. Vijayendra Rao and Michael Walton, eds. Stanford: Stanford University Press, 59-84.

Appadurai, Arjun. 2005. Modernity at Large. Cultural Dimensions of Globalization. London: University of Minnesota Press.

Beck-Gernsheim, Elisabeth. 2006. "Transnationale Heiratsmuster und transnationale Heiratsstrategien. Ein Erklärungsansatz zur Partnerwahl von Migranten” [Transnational Marriage Pattern and Transnational Marriage Strategies. An Explanatory Approach to Marriage Choices of Migrants]. Soziale Welt 57/2: 111-119.

Beck-Gernsheim, Elisabeth. 2007. “Transnational Lives, Transnational Marriages. A Review of the Evidence from Migrant Communities in Europe". Global Networks. A Journal of Transnational Affairs 7/3: 271-288.

Beck-Gernsheim, Elisabeth. 2011. "The Marriage Route to Migration. Of Border Artistes, Transnational Matchmaking and Imported Spouses”. Nordic Journal of Migration Research 1/2: 60-68.

Bhalla, Vibha. 2014. "Arbeitsmigration von Männern, Heiratsmigration von Frauen? Geschlechtsspezifische Apekte von Wanderungen aus Indien in die USA" [Labour Migration of Men, Marriage Migration of Women? Gender Specific Aspects of Migration from India to the USA]. L'homme 25/1: 85-102.

Block, Laura. 2014. "Regulating Membership. Explaining Restriction and Stratification of Family Migration in Europe”. Journal of Family Issues 1-20.

Block, Laura and Saskia Bonjour. 2013. "Fortress Europe or Europe of Rights? The Europeanisation of Family Migration Policies in France, Germany and the Netherlands". European Journal of Migration and Law 15: 203-224.

Bonjour, Saskia and Laura Block. 2016. "Ethnicizing Citizenship, Questioning Membership. Explaining the Decreasing Family Migration Rights of Citizens in Europe”. Citizenship Studies 20/6-7: 779-794.

Charsley, Katharine. 2005. "Vulnerable Brides and Transnational Ghar Damads. Gender, Risk and 'Adjustment' among Pakistani Marriage Migrants to Britain”. Indian Journal of Gender Studies 12: 381-406.

Charsley, Katherine and Anika Liversage. 2015. "Silenced Husbands. Muslim Marriage Migration and Masculinity”. Men and Masculinities 18/4: 489-508.

Charsley, Katherine and Helena Wray. 2015. "Introduction. The Invisible (Migrant) Man”. Men and Masculinities 18/4: 403-423.

Constable, Nicole. 2005. "Introduction. Cross-Border Marriages, Gendered Mobility, and Global Hypergamy". In Cross Border Marriages. Gender and Mobility in Transnational Asia. Nicole Constable, ed. Philadelphia: University of Pennsylvania Press, 1-16. 
Giddens, Anthony. 1992. The Transformation of Intimacy. Sexuality, Love and Eroticism in Modern Societies. Cambridge: Polity Press.

Gutekunst, Miriam. 2016. "Doing Gender und das Regieren der Migration durch Heirat. Eine ethnographische Analyse der wechselseitigen Konstitution von Geschlecht und Grenze" [Doing Gender and the Reigning of Migration through Marriage. An Ethnographic Analysis of the Reciprocal Constitution of Gender and Border]. Feministische Studien 2: 226-240.

Hajnal, John. 1965. "European Marriage Pattern in Perspective". In Population in History. Essays in Historical Demography. David Victor Glass and David Edward Charles Eversley, eds. Chicago: Aldine, 101-143.

Hart, Kimberly. 2007. "Love by Arrangement. The Ambiguity of 'Spousal Choice' in a Turkish Village". Journal of the Royal Anthropological Institute 13: 345-362.

Hockenoes, Paul. 2006. Cutting the Lifeline. Migration, Family and the Future of Kosovo. Berlin, Istanbul: European Stability Initiative.

Hyndman-Rizk, Nelia. 2016. "No Arranged Marriages Here. Migration and the Shift from Relations of Descent to Consent in the Lebanese Diaspora". Journal of Intercultural Studies 37: 303-319.

Kaser, Karl. 1995. Familie und Verwandtschaft auf dem Balkan. Analyse einer untergehenden Kultur [Family and Kinship in the Balkans. Analysis of a Disappearing Culture]. Vienna, Cologne, Weimar: Böhlau.

Kelek, Nelca. 2006. Die fremde Braut. Ein Bericht aus dem Inneren des türkischen Lebens in Deutschland [The Foreign Bride. A Report from the Inner of Turkish Life in Germany]. München: Goldmann.

Kohli, Martin and Patrick Heady. 2010. "Conclusions. Implications for Policy". In Family, Kinship and the State in Contemporary Europe, 3. Perspectives on Theory and Policy. Martin Kohli and Patrick Heady, eds. Frankfurt am Main: Campus, 395-410.

Kosovo Agency for Statistics. 2016. Results of the Labour Force Survey in Kosovo (LFS), 2016. http://ask.rks-gov.net/en/kosovo-agency-of-statistics/add-news/results-ofthe-labour-force-survey-in-kosovo-lfs-2016 (last access 4 October 2017).

Latifi, Tahir. 2016. "Poverty and Social Security from the Perspective of Post-War Political, Social and Family Transformations in Kosovo. Marco- and Micro Level Points of View". Ethnologia Balkanica 18: 249-268.

Lauser, Andrea. 2005. "Translokale Ethnographie" [Translocal Ethnography]. Forum Qualitative Sozialforschung 6/3.

Leutloff-Grandits, Carolin. 2015. "Transnationale Ehen durch die Linse von Gender und Familie. Heiratsmigration aus Kosovos Süden in Länder der EU” [Transnational Marriages through the Lens of Gender and Family. Marriage Migration from the South of Kosovo to the EU Countries]. IMIS 47: 163-193.

Neubauer, Anna und Janine Dahinden. 2012. "Zwangsheiraten" in der Schweiz. Ursachen, Formen, Ausmass ["Forced Marriages" in Switzerland. Reasons, Forms and Scope]. Bundesamt für Migration. 
Massey, Doreen. 1994. "A Global Sense of Place". In Space, Place and Gender. Oxford: Polity Press, 146-156.

Morokvasic, Mirjana. 1987. Jugoslawische Frauen. Die Emigration - und danach [Yugoslav Women. The Emigration - and After]. Basel: Verlag Roter Stern.

Pellander, Saara. 2015. "Collective Threats and Individual Rights. Political Debates on Marriage Migration to Finland”. In Race, Ethnicity and Welfare States. An American Dilemma? Pauli Kettunen, Sonya Michel and Klaus Petersen, eds. Cheltenham, Northampton: Edward Elgar, 107-127.

Razack, Sherene H. 2004. "Imperilled Muslim Women, Dangerous Muslim Men and Civilized Europeans. Legal and Social Responses of Forced Marriage". Feminist Legal Studies 12: 129-174.

Reineck, Janet. 1991. The Past as Refuge. Gender, Migration, and Ideology among the Kosova Albanians. PhD thesis. Berkeley: University of California.

Riaño, Yvonne and Janine Dahinden. 2010. Zwangsheirat. Hindergründe, Massnahmen, lokale und transnationale Dynamiken [Forced Marriages. Backgrounds, Measures, Local and Transnational Dynamics]. Zürich: Seismo.

Ruenkaew, Pataya. 2003. Heirat nach Deutschland. Motive und Hintergründe thailändisch-deutscher Eheschliessungen [Marriage to Germany. Motives and Backgrounds of Thai-German Marriages]. Frankfurt a. M.: Campus.

Schiffauer, Werner. 1991. Die Migranten aus Subay. Türken in Deutschland. Eine Ethnographie [The Migrants from Subay. Turks in Germany. An Ethnography]. Stuttgart: Klett-Cotta.

Schmidt, Gabi. 2011. "Migration and Marriage. Examples of Border Artistry and Cultures of Migration?”. Nordic Journal of Migration Research 1/2: 55-59.

Schröttle, Monika. 2007. "Zwangsverheiratung, Gewalt und Paarbeziehungen von Frauen mit und ohne Migrationshintergrund in Deutschland. Differenzierung statt Polarisierung" [Forced Marriages, Violence and Partnership Relations of Women with and without Migration Background in Germany. Differentiation instead of Polarization]. In Zwangsverheiratung in Deutschland. Baden-Baden: Bundesministerium für Familie, Senioren, Frauen und Jugend, 149-170.

Straßburger, Gaby. 2001. "Warum aus der Türkei? Zum Hintergrund transnationaler Ehen der zweiten Migranten-Generation" [Why from Turkey? About the Background of Transnational Marriages of the Second Generation]. Migration und Soziale Arbeit 1: 34-39.

Straßburger, Gaby and Can M. Aybek. 2015. "Marriage Migration from Turkey to Germany. How Underprivileged Couples Cope with Immigration Regulations or Not”. In Marriage Migration and Intercultural Relationships. Elli Heikkilä and Daniel Rauhut, eds. Turku: Institute for Migration, 81-103.

Strasser, Sabine and Jelena Tosic. 2014. "Egalität, Autonomie und Integration. PostMultikulturalismus in Österreich" [Egality, Autonomy and Integration. PostMulticulturalism in Austria]. In Kultur, Gesellschaft, Migration. Die reflexive Wende 
der Migrationsforschung. Boris Nieswand and Heike Drotbohm, eds. Wiesbaden: Springer, 123-151.

Timmerman, Christiane. 2006. "Gender Dynamics in the Context of Turkish Marriage Migration. The Case of Belgium”. Turkish Studies 7/1: 125-143.

Timmerman, Christiane. 2008. "Marriage in a 'Culture of Migration'. Emirdag Marrying into Flanders". European Review 16/4: 585-594.

Toprak, Ahmet. 2007. "Geschlechterrollen und Geschlechtererziehung in traditionellen türkischen Familien. Verheiratung des Mannes als Disziplinarmaßnahme" [Gender Roles and Gender Socialization in Traditional Turkish Families. Marrying of a Man as a Means of Disciplining]. In Zwangsverheiratung in Deutschland. Baden-Baden: Bundesministerium für Familie, Senioren, Frauen und Jugend, 171-186. 